\title{
The Unpredictable Lightness of History in Nicolas Cavaillès' Novellas on the Mauritius Islands
}

\section{Fevronia Novac ${ }^{1}$}

Nicolas Cavaillès ponders on a philosophy of history mixed with humour and irony in his historical narratives of remote islands in the Indian Ocean in two of his novellas: Life of Mr. Legaut (the story of a Huguenot who is forced to leave his native France and travels to these islands) and The Dead on the Donkey, where the wanderings of un unfortunate donkey across the Mauritius Island allow the narrator to relate the history of the island and its tragic trajectory to modernity. The idea of Western history as progressive evolution is rolled upside down with irony in Cavaillès's philosophical reflection on the circumstances leading to colonial expeditions in Life of $M r$. Leguat (2013) and in the successive destruction of the Mauritius Island in the novella The Dead on the Donkey (2018). If Cavaillès builds his books hermeneutically, he also defies hermeneutics by denying all forms of possible understanding of the events described. The actions of his protagonists, human or animal, are the result of circumstances that are well known, but so absurd that they cannot form a historical narrative. If they did, this narrative would look like a hybrid of Beckett's absurd and Cioran's despair. Anti-Hegelian, since history here does not lead to individual freedom, Cavaillès's conception of history equally challenges Nietzsche's representation of unhistorical temporality in an attempt to solve humanity's relation to the past for enacting a more desirable future. In far away Edenic islands, colonized by powerful states and inhabited by human and animal slaves, no philosophy could make sense of history. [Article copies available for a fee from The Transformative Studies Institute. E-mail address: journal@transformativestudies.org Website: http://www.transformativestudies.org (C2021 by The Transformative Studies Institute. All rights reserved.]

KEYWORDS: Nicolas Cavaillès, French Novella, History, Mauritius Island.

\footnotetext{
${ }^{1}$ Fevronia Novac, Ph.D., Canadian Cultural Centre, Paris, poet and essayist. She earned a doctorate in French literature from the University of Ottawa (Canada) in 2002 with a thesis on the critical reception of Alain Robbe-Grillet's work. She has published poems and research articles in Romania, Canada, the United States, and France. Her volumes of poetry are: Barbie, Mafalda, Fevi (Cartea Românească, 1997), Marie (Paralela 45, 2007), Ophelia Is Wearing Perfume (Nova International Press, 2008), and A la Vie (Vinea Press, 2017). She is featured in collective volumes: Fictiuni (Bucharest: Litera Press, 1992), Clubul literar (Tracus Arte Press, 2015), and in the anthology UNIVERSITAS. Once Upon a Time, a Literary Circle. Bucharest: Ed. M.N.L.R., 2008. She also authored a book of essays in cultural anthropology, The Bear Is Not Dancing. Essays on the Cultures of the First Nations of North America (Tiparg, 2011). Address correspondence to: Fevronia Novac, e-mail: fevronian@gmail.com.
} 